\title{
The Role of Maternal Factors, Postnatal Nutrition, Weight Gain, and Gender in Regulation of Serum IGF-I among Preterm Infants
}

\author{
EVA ENGSTRÖM, AIMON NIKLASSON, KERSTIN ALBERTSSON WIKLAND, \\ UWE EWALD, AND ANN HELLSTRÖM
}

\begin{abstract}
Göteborg Pediatric Growth Research Center [E.E., A.N., K.A.W., A.H.], Department of Pediatrics, Institute of the Health of Women and Children, Department of Clinical Neurosciences [A.H.], Section of

Ophthalmology, The Sahlgrenska Academy at Göteborg University, S-416 85 Göteborg, Sweden, Department of Women's and Children's Health [U.E.], Uppsala University, S-751 85 Uppsala, Sweden
\end{abstract}

\begin{abstract}
ABST
IGF-I is important for somatic growth and development of the
human fetus and neonate. IGF-I also plays an important role in
normal vascularization of human retina, as it has been suggested
that insufficient IGF-I may be a factor in the development of
retinopathy of prematurity. The principal regulator of the bio-
availability of IGF-I in the circulation is IGF binding protein 3
(IGFBP-3). The aim of this study was to study factors associated
with postnatal serum concentrations of IGF-I and of IGFBP-3 in
preterm infants from birth to an age corresponding to 40 wk
postmenstruation. We conducted a prospective, longitudinal
study in which we measured serum IGF-I and IGFBP-3 concen-
trations in 76 preterm infants from birth (postmenstrual ages
$23-32$ wk) until discharge from hospital around 40 wk. Infor-
mation regarding nutrition, weight gain, maternal factors, and
treatment with corticosteroids were collected weekly. Variables
found to be associated with postnatal change over time of serum
IGF-I and IGFBP-3 were postmenstrual age ( $p<0.001$ ), weight
gain (standard deviation score) ( $p<0.001)$, and enteral intake of
protein $(p<0.001$ ). Male gender was associated with lower
IGF-I levels ( $p<0.001$ ). The relationship between protein intake
and IGF-I (and also between protein intake and IGFBP-3) was
\end{abstract}
ABSTRACT

positive, as was the relationship between weight gain and IGF-I (and between weight gain and IGFBP-3). These results indicate that the degree of prematurity, low enteral protein intake, male gender, and slow weight gain are associated with a slower postnatal increase of IGF-I in preterm infants. (Pediatr Res 57: 605-610, 2005)

$\quad$ Abbreviations
AGA, appropriate for gestational age
BPD, bronchopulmonary dysplasia
CI, confidence interval of the mean $(95 \%)$
GA, gestational age in weeks
IGFBP-3, IGF binding protein 3
NEC, necrotizing enterocolitis
PMA, postmenstrual age in weeks
ROP, retinopathy of prematurity
SDS, standard deviation score
SGA, small for gestational age
ASDS, individual change in SDS during a predefined time
period

IGF-I, which is important for somatic growth and development of the human fetus and neonate, is detectable in fetal tissues from 9 wk of gestation (1) and in the fetal circulation from $15 \mathrm{wk}$ (2). Receptors for IGF-I are found in various tissues early in gestation (3), and fetal tissues seem to have enhanced sensitivity to IGF-I compared with later in life (4). Using cordocenteses, it has been possible to determine the

Received November 20, 2003; accepted August 16, 2004.

Correspondence: Eva Engström, M.D., Göteborg Pediatric Growth Research Centre, Department of Pediatrics, The Queen Silvia Children's Hospital, Sahlgrenska University Hospital, S-416 85 Göteborg, Sweden; e-mail: eva.engstrom@vgregion.se

Supported by grants from The Göteborg Medical Society, Första Majblomman, The Sven Jerring Foundation, The Swedish Medical Research Council (\#7509, \#10863, and \#13515), and The Health and Medical Care Board of the Västra Götaland Region.

DOI: 10.1203/01.PDR.0000155950.67503.BC "normal" range of IGF-I in fetal serum and to define a positive correlation between serum concentration of IGF-I and gestational age (5-10). IGF-I levels are similar in arterial and venous cord serum, suggesting a fetal origin (1). The bioavailability of IGF-I is regulated by IGFBP. As in children and adults, IGFBP-3 is the principal carrier of IGF-I during late intrauterine life $(11,12)$. Preterm infants have lower serum levels of IGF-I than term infants, and size at birth is correlated with the level of IGF-I in cord serum $(7,13,14)$. Therefore, infants born SGA have lower IGF-I values than infants born AGA (5,10,13,15-17). Nutritional status, i.e. intake of protein and of total energy, has been shown to regulate IGF-I (18), and measurements of IGF-I can be used to assess changes in the nutritional status of malnourished patients (19). Studies in both 
children and adults have shown that serum IGF-I concentrations fall with fasting and rise with re-feeding (20-22).

IGF-I plays an important role in neovascularization (23), and it has been suggested that lack of IGF-I in the early weeks of life, followed by a slow increase, is likely to increase the risk for development of ROP (24). It has also been observed that the greater the duration of low IGF-I, the more severe the ROP (25).

We performed a prospective study with the aim of determining the factors that may influence the longitudinal development of serum IGF-I and IGFBP-3 in a group of very preterm infants from birth to an age corresponding to $40 \mathrm{wk}$ of gestation.

\section{MATERIALS AND METHODS}

Characteristics and selection of study group. Infants born at a PMA of $<32$ wk at The Queen Silvia Children's Hospital in Göteborg between December 1999 and April 2002 and at Uppsala University Hospital between February 2001 and April 2002 were recruited for the study. Exclusion criteria were inability to complete postnatal clinical follow-up until an age corresponding to 40 postmenstrual weeks, and any conspicuous congenital anomaly.

The parents of 70 children gave permission for participation at The Queen Silvia Children's Hospital. At Uppsala University Hospital, 15 infants were identified and recruited as potential participants. Seven infants in the combined group were excluded because of incomplete data, including missing blood samples during the first weeks. During data collection, two infants were moved to another hospital, leaving a total of 76 study subjects ( 34 male, 42 female), 64 from The Queen Silvia Children's Hospital and 12 from the Uppsala University Hospital. The median PMA at birth (based on fetal ultrasonography, performed at wk 16-18 postmenstruation) was $27.3 \mathrm{wk}$ (range, $23.6-31.7 \mathrm{wk}$ ). Trained nurses at the neonatal intensive care unit measured weight at birth. Thereafter, weight was measured and recorded weekly until discharge from hospital.

Median birth weight was $1283 \mathrm{~g}$ (range, 530-1760 g) and -1.3 SDS (range, -5.0 to 1.9 SDS), (Table 1). During the first postnatal weeks, all infants lost weight. Twenty (26\%) were born SGA with a birth weight below -2 SDS. In addition, 49 infants born AGA experienced postnatal growth retardation, such that $69 / 76(90.8 \%)$ had a weight below -2 SDS during the neonatal period. Twenty-seven (27/76) of the infants were included in an earlier basic science study on the role of IGF-I in ROP (24) and the whole study group $(n=76)$ is presented in a clinical study on ROP (25).

The ethics committees of the medical faculties at Göteborg and Uppsala universities approved the study, and the parents of the infants gave informed consent.

Nutrition. All infants were hospitalized in neonatal intensive care units and nourished according to the routines for premature infants at the units. Enteral feeding with increasing amounts of breast milk was introduced early $(2-48 \mathrm{~h}$ after birth). If full enteral feeding was not achieved, supplementary parenteral nutrition with glucose, amino acids, and fat was given. The breast milk given to infants with a birth weight $<1500 \mathrm{~g}$ was fortified with $0.8 \mathrm{~g}$ protein $/ 100 \mathrm{~mL}$ (gradually introduced over $1 \mathrm{wk}$ ) from $10 \mathrm{~d}$ of age until the infant weighed approximately $2 \mathrm{~kg}$. If the amount of mother's milk was insufficient, unpooled donor milk was given until 35 wk of PMA. Thereafter, formula was introduced. The nutritional intake recorded in each infant's record was used to calculate the calories and protein taken during the period in which blood was sampled. At The Queen Silvia Children's Hospital, most of the mothers' and donors' breast milk was analyzed every second week for protein and calorie content (26), and results of these analyses were used to calculate nutrient intake. In cases where breast milk was not analyzed, the mean value of all analyses $(n=272)$ was used $(0.7 \mathrm{kcal} / \mathrm{mL}$ and $1.7 \mathrm{~g}$ protein $/ 100 \mathrm{~mL}$ before 33 wk PMA and $1.5 \mathrm{~g}$ protein/100 $\mathrm{mL}$ after 33 wk PMA). These values are similar to those obtained in other studies (27).

The nutritional goal was to follow the recommendations for infants with birth weight $<1500 \mathrm{~g}$, to achieve a daily intake of $3.5 \mathrm{~g}$ protein $/ \mathrm{kg}$ and $120-130 \mathrm{kcal} / \mathrm{kg}(28,29)$.

Twenty-eight infants (28/76) were given only human breast milk and glucose infusion $(10 \%)$, without any parenteral supplementation with fat or amino acids from the first days of life. The other infants (48/76) received breast milk plus parenteral fat and amino acids added to the glucose infusion. The parenteral nutrition was supplied for a mean of $7 \mathrm{~d}(0-155 \mathrm{~d})$, including four infants with NEC who received infusions for an extended period of time (Table 2). All infants were fed human breast milk and, in most cases (65/76), the milk was fortified. None were formula fed before a PMA of 35 wk. In 22 infants, the nutrition (enteral and parenteral) was recorded daily, whereas in the remaining 54 infants, daily enteral nutrition data were summarized as mean per week.

Morbidity. Twenty-two infants (22/76) were diagnosed with BPD, based on pathologic x-ray findings and need for oxygen supplementation at 36 wk PMA (30). Thirteen infants (13/76) had ROP stage 3 according to the International Classification (31). Four infants (4/76) had NEC with gut perforation and required surgery.

Mothers of seventeen infants (17/76) had preeclampsia and mothers of 14 infants had preterm rupture of the membranes (PROM, $>24 \mathrm{~h}$ before delivery). A majority of the study group (56/76) received antenatal treatment with betamethasone (two doses, $12 \mathrm{mg}$ i.v. given at 12-h interval). Postnatal treatment with dexamethasone $(0.2-0.5 \mathrm{mg} / \mathrm{kg} / \mathrm{d}$, divided into two doses) was given for $3 \mathrm{~d}$ to $12(12 / 76)$ infants in an attempt to shorten the time on the ventilator and to facilitate extubation, a regime used during the time of the present study. The dexamethasone was then tapered off over 4-5 d. If the infant could not be weaned off the ventilator, the treatment was repeated after approximately $1 \mathrm{wk}$

IGF-I and IGFBP 3 analysis. Venous blood-samples $(0.5 \mathrm{~mL})$ were drawn weekly, and the serum was stored at $-20^{\circ} \mathrm{C}$ to $-80^{\circ} \mathrm{C}$ until assayed. All samples from an individual were analyzed in the same assay. IGF-I was measured in duplicate using an IGFBP-blocked RIA without extraction and in the presence of $\sim 250$-fold excess of IGF-II (32) (Mediagnost GmbH, Tübingen, Germany). The intra-assay coefficient of variation (CV) was $15.7 \%$ at 10.2 $\mu \mathrm{g} / \mathrm{L}$ and $9.6 \%$ at $34.5 \mu \mathrm{g} / \mathrm{L}$. The interassay $\mathrm{CV}$ was $23.9 \%$ at $10.2 \mu \mathrm{g} / \mathrm{L}$ and $12.1 \%$ at $34.5 \mu \mathrm{g} / \mathrm{L}$.

IGFBP-3 was measured by RIA (Mediagnost $\mathrm{GmbH}$ ) (32). The intra-assay $\mathrm{CV}$ was $6.9 \%$ at $900 \mu \mathrm{g} / \mathrm{L}, 6.9 \%$ at $1800 \mu \mathrm{g} / \mathrm{L}$, and $7.4 \%$ at $3800 \mu \mathrm{g} / \mathrm{L}$. The corresponding interassay CV was $15 \%, 14 \%$, and $11 \%$, respectively.

Statistical methods. A multiple regression analysis, allowing for repeated values within each individual, where IGF-I was assumed to be a function of the explanatory variables (PROC MIXED in SAS Release 8.12, SAS Institute, Cary, NC) was performed. With repeated measurements on the same individual, the values for different individuals are independent, whereas there is often a within-individual dependence. Therefore, the ordinary regression analysis is not suitable. Instead a random coefficient regression model can be estimated where the coefficients (a, b1, b2, etc.) are allowed to vary from one individual to the next. In our model, the intercept, a, is individual, allowing child 1 to have a different intercept than child 2, which means that the model of the development of serum IGF-I over time takes into account that each infant have its own starting level. In the random coefficient model, all values of all the study subjects were used.

As it has been reported that low IGF-I levels during wk 30-33 PMA are associated with morbidity (24), we also calculated the mean IGF-I value for

Table 1. Gestational ages and birth weights in the study population $(n=76)$

\begin{tabular}{|c|c|c|c|c|c|}
\hline & \multicolumn{4}{|c|}{ Gestational age (wk) } & \multirow[b]{2}{*}{$\begin{array}{c}\text { Total } \\
(n=76)\end{array}$} \\
\hline & $\begin{array}{c}23-25 \\
(n=20)\end{array}$ & $\begin{array}{c}26-27 \\
(n=20)\end{array}$ & $\begin{array}{c}28-29 \\
(n=23)\end{array}$ & $\begin{array}{c}30-31 \\
(n=13)\end{array}$ & \\
\hline Range & $530-950$ & $685-1100$ & $625-1540$ & $710-1760$ & $530-1760$ \\
\hline Median birth weight (SDS) & -0.82 & -1.28 & -1.48 & -1.37 & -1.3 \\
\hline Range & -2.8 to 1.9 & -3.5 to 0.8 & -4.4 to 1.1 & -5.0 to -0.6 & -5.0 to 1.9 \\
\hline
\end{tabular}


Table 2. Number of infants exclusively enterally fed and those given parenteral nutrition in relation to median gestational age, median birth weight, and gender

\begin{tabular}{|c|c|c|c|c|c|}
\hline \multirow{2}{*}{$\begin{array}{c}\text { Nutrition } \\
\text { No. of days }\end{array}$} & \multirow{2}{*}{$\begin{array}{c}\begin{array}{c}\text { Enteral nutrition } \\
\text { exclusively }\end{array} \\
0(n=28)\end{array}$} & \multicolumn{4}{|c|}{ Parenteral nutrition with fat and amino acids } \\
\hline & & $\begin{array}{c}1-5 \\
(n=24)\end{array}$ & $\begin{array}{c}6-10 \\
(n=13)\end{array}$ & $\begin{array}{c}11-15 \\
(n=4) \\
\end{array}$ & $\begin{array}{c}>15^{*} \\
(n=7)\end{array}$ \\
\hline Median gestational age (wk) & 29.9 & 26.4 & 27.3 & 25.1 & 24.7 \\
\hline Range & $24.9-31.7$ & $24.7-29.6$ & $25.0-30.1$ & $24.4-25.3$ & $23.6-26.6$ \\
\hline Median birth weight (g) & 1345 & 830 & 1195 & 700 & 700 \\
\hline Boys $(n)$ & 14 & 9 & 8 & 1 & 2 \\
\hline
\end{tabular}

* Includes four infants (one boy and three girls with necrotizing enterocolitis leading to surgery in whom partial parenteral nutrition were given for 19, 36 , 44 and $>155 \mathrm{~d}$, respectively. Median gestational age, $24.9 \mathrm{wk}$ (range, 24.4-29.6 wk); median birth weight, $737.5 \mathrm{~g}$ (range, 535-780 g).

each infant during this time interval. A linear regression analysis was performed to analyze which explanatory variables that affected the mean IGF-I during wk 30-33 (using SPSS Release 11.0.0, SPSS Inc., Chicago, IL). An adjusted $R^{2}$, with a correction for degrees of freedom, was used as a measure of model fit, with a correction for degrees of freedom. Thirteen infants were $>30$ wk of gestation at birth and thus did not have measurements during the investigated time period (wk 30-33 PMA) and were, as a consequence, excluded, leaving 63 infants in the analysis of the mean values of IGF-I.

The following were considered possible explanatory variables: PMA, birth weight (SD), gender (male), weight development (SDS), enteral energy-intake $(\mathrm{kcal} / \mathrm{kg})$, enteral intake of protein $(\mathrm{g} / \mathrm{kg})$, preeclampsia, PROM $>24 \mathrm{~h}$ before delivery, and antenatal and/or postnatal treatment with corticosteroids. When no information regarding weight, energy, and protein intake was available on the day in which the sample for IGF-I was drawn, the values were estimated by interpolation. For kilocalorie and protein variables, the interpolation for the missing value at time $t$ was made using a linear regression based on the measurement made at the nearest time point before $t$ and the measurement made at the nearest time point after $t$. The interpolation concerning weight development was modeled as a function of time (polynomial of degree 4) and the missing values were interpolated using this function. Of the values used in the analysis, $87 \%$ were actual measurements. All enteral intake variables are expressed as the amount per kilogram.

The variables PMA (adjusting to comparable biologic maturity) and weight expressed in SDS were used, instead of number of days from birth and weight in grams. This made it possible to consider a deviation from expected weight according to age (33) as well as comparing the results between infants irrespective of gestational age at birth.

In the analysis of which factors are associated with the mean serum IGF-I level, the repeated observations on enteral intake of energy as well as protein were summarized for each child, as the number of days to reach $120 \mathrm{kcal} / \mathrm{kg}$ and $3.5 \mathrm{~g} / \mathrm{kg}$, respectively. In a corresponding way, the weight change (measured in SDS) was summarized as the number of days to reach the lowest weight (SDS) as well as the magnitude of the maximal postnatal decline in weight (SDS). Analysis of IGFBP-3 was performed in the same fashion as the IGF-I analysis. $p$ Values $<0.05$ were considered significant.

\section{RESULTS}

IGF-I: Change over time. The following variables were found to be significantly associated with the change in serum IGF-I: PMA (weeks), gender, weight (SDS), and enteral intake of protein $(\mathrm{g} / \mathrm{kg})$.

Postmenstrual age had a positive but nonlinear relationship with IGF-I $(p<0.001)$. Analyzing the study group divided into subgroups (infants with different GA at birth analyzed separately), the results indicate that, independent of GA at birth, the rate of changes in IGF-I decreased over time, i.e. the rate was not constant, although positive (data not shown). This nonlinearity in IGF-I is accounted for in the model by including a quadratic term for biologic age. The relationship between enteral protein intake and IGF-I was positive, as was the relationship between weight development and IGF-I $(p<$ 0.001). After having accounted for age, gender, and weight
(SDS), enteral protein intake was still a significant modulator of IGF-I $(p<0.001)$. When analyzing the relationship between protein supplementation of the breast milk and IGF-I changes (data not shown), the results indicated that before an attained weight of $2 \mathrm{~kg}$, the average increase in IGF-I was stronger than after a weight of $2 \mathrm{~kg}$ when the average increase was still positive but not as strong (Fig. 1). There was also a positive relationship between IGF-I and total enteral energy intake (kcal). However, when PMA was included in the model, the kilocalorie variable was no longer significant.

Male gender was associated with lower IGF-I levels $(p<$ 0.001) at all PMA (Fig. 2).

IGF-I: Mean value wk 30-33 PMA. In the analysis of mean serum IGF-I values during wk 30-33 PMA, the variables gender, birth weight (SDS), difference between birth weight SDS and lowest weight SDS ( $\Delta$ SDS), and days until reaching an enteral intake of $3.5 \mathrm{~g}$ protein $/ \mathrm{kg}$ were found to be significant. The adjusted $R^{2}$ was 0.51 .

The relationship between the SDS for birth weight and mean IGF-I level was positive (the higher birth weight SDS, the higher the mean serum IGF-I level; $p<0.001$ ), whereas male gender was associated with lower mean IGF- I levels $(p=$

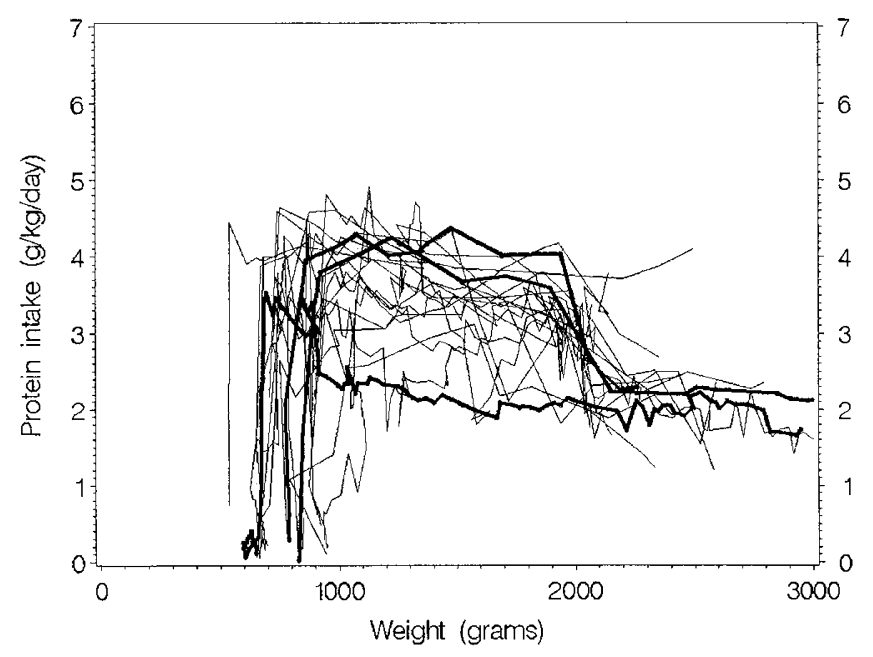

Figure 1. Daily protein intake $(\mathrm{g} / \mathrm{kg})$ in a subgroup of infants with gestational age $>24$ wk and $<28$ wk and birth weight $<1000 \mathrm{~g}(n=19)$ without any major clinical complications. Heavy lines exemplify three different infants. Tolerance to protein supplementation and termination because of direct breast feeding or attained size at approximately $2 \mathrm{~kg}$ influence the courses. 


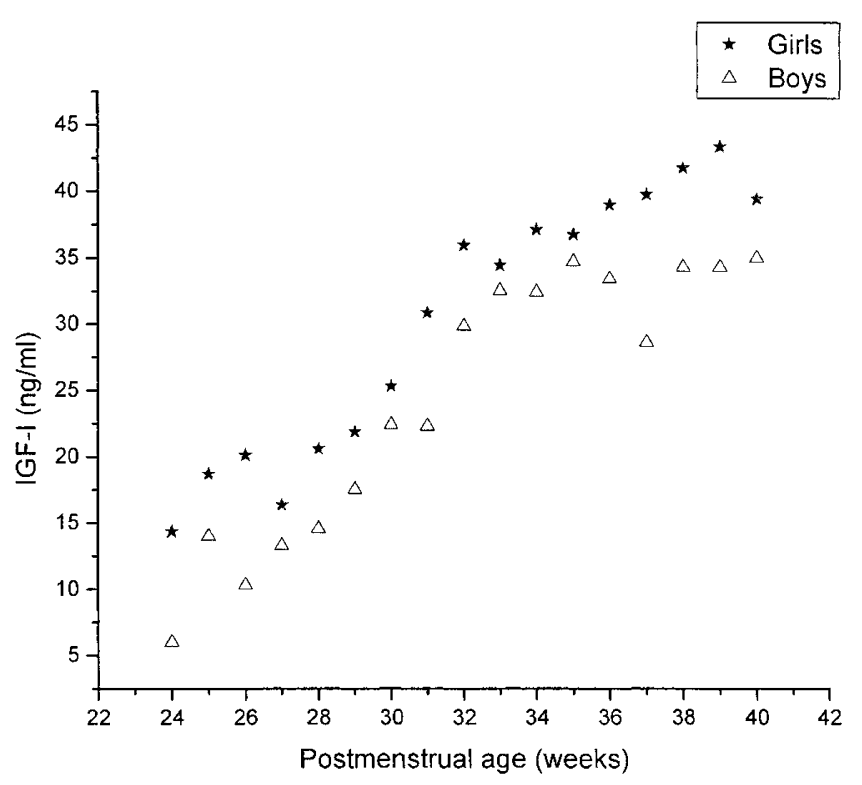

Figure 2. Mean values, in each gestational week, for all IGF-I samples drawn in girls and boys, respectively. Girls $(n=42)$ are depicted as stars and boys $(n=34)$ as triangles.

0.001). The children who had a poor weight gain also had lower mean serum IGF-I during wk 30-33 PMA $(p<0.001$; Fig. 3). In addition, a longer time to reach a daily enteral intake of $3.5 \mathrm{~g}$ protein $/ \mathrm{kg}$ was associated with a lower mean IGF-I level at wk $30-33$ PMA $(p=0.006)$. No association was observed between the mean IGF-I at wk 30-33 and the number of days to reach a daily oral energy intake of $120 \mathrm{kcal} / \mathrm{kg}$.

For 54 infants, daily nutritional data were summarized as mean per week before calculation. This method was compared with a calculation from daily data for 22 infants. The two methods showed no differences in result.

Excluding the infants with morbidity from the analysis, the estimate of the model increased for enteral protein intake and weight (SDS) although the degree of significance was the

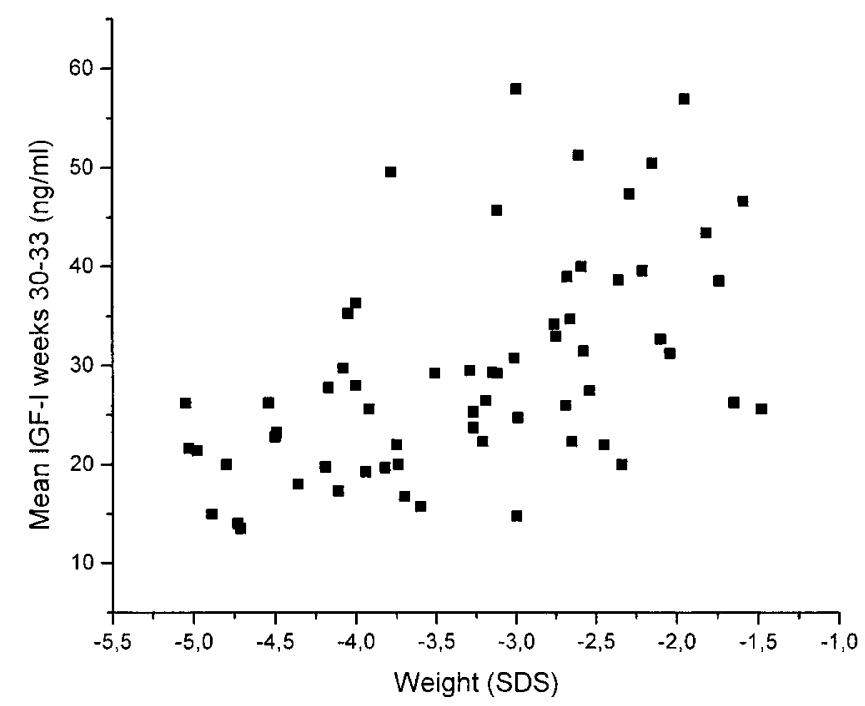

Figure 3. Scatterplot in 63 infants (PMA $<30 \mathrm{wk}$ ) demonstrating an association between lowest weight (SDS) during the neonatal period and the mean IGF-I level in wk 30-33 $(R=0.5, p=<0.001)$. same. The maternal factors-preeclampsia, PROM $>24 \mathrm{~h}$ before delivery, or antenatal or postnatal with corticosteroidsdid not have significant effect on postnatal serum IGF-I levels.

IGFBP-3: Change over time. In the random coefficient model (using PROC MIXED), the following variables were found to be significantly associated $(p<0.001)$ with the development of IGFBP-3: PMA (weeks), weight gain (SDS), and enteral intake of protein $(\mathrm{g} / \mathrm{kg})$.

There was no association between gender and longitudinal development of IGFBP-3 over time. Also, for IGFBP-3, a quadratic term for PMA was tried but was not significant, indicating a linear relationship with PMA and IGFBP-3. In the analysis of the change in IGFBP-3, neither infant morbidity, preeclampsia, nor antenatal treatment with corticosteroids was significant. However, PROM ( $>24 \mathrm{~h}$ before delivery) was followed by a more rapid rise in the IGFBP-3 values (data not shown).

IGFBP-3: Mean value wk 30-33 PMA. The analysis of the mean IGFBP-3 during wk 30-33 PMA revealed a significant relationship with birth weight (SDS; low birth weight SDS was associated with low mean IGFBP-3; $p<0.001$ ), gender (lower mean IGFBP-3 for boys; $p=0.027$; Fig. 4 ), and change in weight (large decrease in weight SDS was associated with low mean IGFBP- $3 ; p<0.001)$. We found no association between the enteral intake of protein and the mean value of IGFBP-3. In addition, the explanatory power of the model for IGFBP-3 was less than for IGF-I $\left(R^{2}=0.37\right.$ versus $R^{2}=0.51$ for IGF-I).

Postnatal treatment with corticosteroids was not significant.

\section{DISCUSSION}

In this study, we found that enteral protein intake $(\mathrm{g} / \mathrm{kg})$, weight (SDS), gender, and PMA were associated with postnatal change in serum IGF-I levels in very preterm infants. The lower serum IGF-I levels among the most preterm infants at birth had no association with the attained mean value of serum

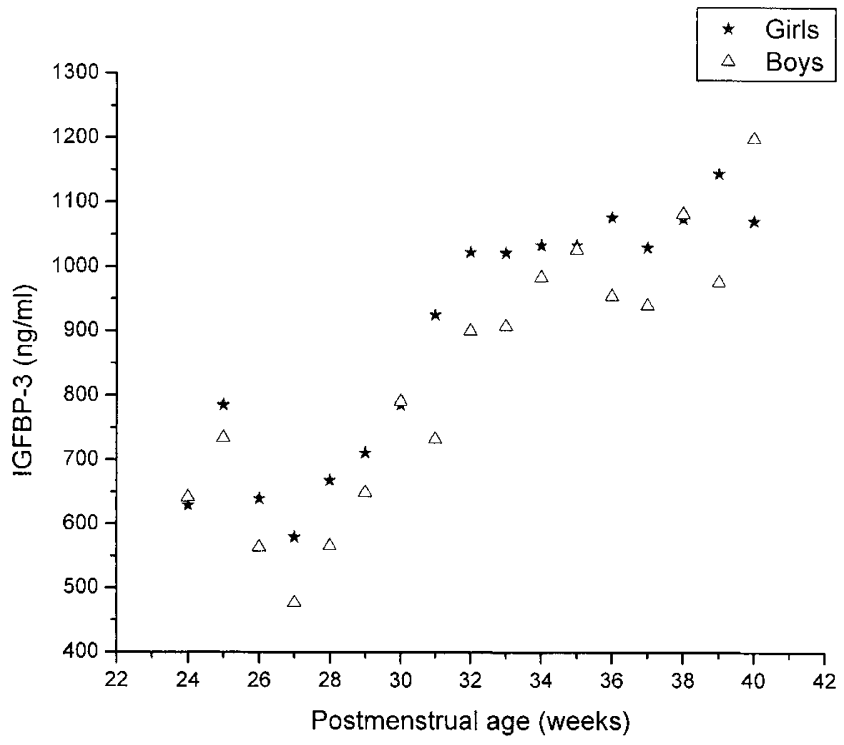

Figure 4. Mean values, in each gestational week, for all IGFBP-3 samples drawn in girls and boys, respectively. Girls $(n=42)$ are depicted as stars and boys $(n=34)$ as triangles. 
IGF-I at wk 30-33 PMA. However, there was a significant association with PMA and IGF-I, reflecting the physiologic development over time $(7,13,14)$.

It may be speculated that the introduction and withdrawal of protein-fortified breast milk is a determinant of the observed nonlinear relationship between PMA and the change in IGF-I over time, with a stronger positive relationship at a lower PMA than higher. In addition, the sooner the daily enteral intake of protein reached a level of $3.5 \mathrm{~g} / \mathrm{kg}$, the higher the mean IGF-I during wk 30-33. Furthermore, the protein content in breast milk is known to decline over time (34). These abovementioned factors often coincide with weaning from tubefeeding and step-wise introduction of direct breast-feeding.

A positive influence of calorie intake upon IGF-I levels has been described $(18,35,36)$. We also observed a relationship between IGF-I and calorie intake. However, when PMA was included in the model, the calorie variable was no longer significant. An explanation of the difficulties in estimating the effect of energy intake could be that this variable is highly correlated with protein intake and protein intake is more important than the energy intake in very preterm infants. Smith et al. (35) reported that increasing protein intake produced a quadratic increase in the IGF-I levels, whereas the relationship between calorie-intake and IGF-I was linear, which supports this possibility.

It has been suggested that the level of IGF-I may be an indicator of nutritional status, i.e. the uptake of nutrients in sick preterm infants (37). This study was an observational study and, based on estimated enteral intake, the causality cannot be proven. Interestingly, in the four infants requiring surgery for NEC, and thereafter experiences by periods of poor enteral nutrition, low levels of serum IGF-I were demonstrated (although not significantly different from the rest of the study group). The small number of observations or compensation by parenteral infused protein may explain this.

Preterm infants with AGA birth weight had higher serum IGF-I levels than infants born SGA or with a prolonged negative postnatal weight development. The analyses also indicated that poor weight gain, leading to postnatal growth retardation, resulted in lower levels of serum IGF-I. This is in line with reports stating that size at birth is correlated with the cord blood IGF-I concentrations $(5,10,13,15-17)$.

AGA infants who are born preterm have increasing serum IGF-I and reach the same values at an age corresponding to term as infants born AGA at term (38). Thus, it seems that weight appropriate for age is as important at birth as during the neonatal period for increasing the serum IGF-I to the levels in AGA infants, and that postnatal growth retardation might be as harmful as intrauterine growth retardation.

We observed a gender difference in which boys had lower serum IGF-I and IGFBP-3 than girls, more pronounced for IGF-I, as has been described in older children $(39,40)$. Results from measurements of IGF-I in serum of fetuses and preterm or term newborn infants have been more variable, as some groups find no difference in serum IGF-I concentrations between the male and female gender $(6,10,13,15)$ and others report higher IGF-I in girls than boys $(41,42)$. Reasons for this gender difference are not clear, but it has been suggested that differ- ences in sex steroids could influence the secretion of IGF-I in utero (43).

None of our analyses revealed a strong relationship between maternal factors and postnatal serum IGF-I or IGFBP-3, although preeclampsia has been reported to be associated with an increased IGF-I concentration in the cord blood and an elevation of binding proteins in the wall of the umbilical artery (44). PROM is associated with intra-amniotic microbial invasion and inflammation (45). Inflammatory reactions have been reported to reduce serum IGF-I (46). In our limited study group, however, we found no association between PROM and serum IGF-I levels. There was, however, a significant elevation of the serum IGFBP-3.

Neither antenatal nor postnatal treatment with corticosteroids appeared to alter serum IGF-I significantly. An explanation for this may be that we used moderate doses of dexamethasone for short periods to facilitate extubation. A single dose of dexamethasone has been reported not to affect the GH-IGF-I axis in pregnant women (47), and Kajantie et al. (41) and Bloomfield et al. (42) have indicated that the influence of corticosteroids on IGF-I and IGFBP-3 might be dose dependent.

Low serum levels of IGF-I in preterm infants have been shown to be associated with increased morbidity. It has been suggested that an early lack of IGF-I followed by a slow increase could predispose to the development of ROP $(23,24)$. It has also been shown that the greater the duration of low IGF-I, the more severe the ROP (25).

In conclusion, our results indicate that the degree of prematurity, a low enteral protein intake, male gender, and slow weight gain or weight loss are associated with a slower longitudinal postnatal increase of serum IGF-I in preterm infants.

Future studies may reveal whether enhanced nutrition or other interventions, such as supplementation of IGF-I, will affect the postnatal serum IGF-I levels, or whether restoring serum IGF-I levels to intrauterine levels is of benefit in preterm infants.

Acknowledgments. The authors thank Eva Andersson for skillful help with statistics, the staff at the neonatal units, Marie Sellhed, Kerstin Wållgren, Anne-Maj Ling, and Lena Ingelsson for assistance and examinations of patients, and Lisbeth Larsson and Chatarina Löfqvist at GPGRC laboratory for technical support.

\section{REFERENCES}

1. Wang HS, Chard T 1992 The role of insulin-like growth factor-I and insulin-like growth factor-binding protein-1 in the control of human fetal growth. J Endocrinol 132:11-19

2. Ashton IK, Zapf J, Einschenk I, MacKenzie IZ 1985 Insulin-like growth factors (IGF) 1 and 2 in human foetal plasma and relationship to gestational age and foetal size during midpregnancy. Acta Endocrinol (Copenh) 110:558-563

3. Sara VR, Hall K, Misaki M, Fryklund L, Christensen N, Wetterberg L 1983 Ontogenesis of somatomedin and insulin receptors in the human fetus. J Clin Invest 71:1084-1094

4. Gluckman PD, Grumbach MM, Kaplan SL 1981 The neuroendocrine regulation and function of growth hormone and prolactin in the mammalian fetus. Endocr Rev 2:363-395

5. Lassarre C, Hardouin S, Daffos F, Forestier F, Frankenne F, Binoux M 1991 Serum insulin-like growth factors and insulin-like growth factor binding proteins in the human fetus. Relationships with growth in normal subjects and in subjects with intrauterine growth retardation. Pediatr Res 29:219-225 
6. Arosio M, Cortelazzi D, Persani L, Palmieri E, Casati G, Baggiani AM, Gambino G, Beck-Peccoz P 1995 Circulating levels of growth hormone, insulin-like growth factor-I and prolactin in normal, growth retarded and anencephalic human fetuses. J Endocrinol Invest 18:346-353

7. Pirazzoli P, Cacciari E, De Iasio R, Pittalis MC, Dallacasa P, Zucchini S, Gualandi S, Salardi S, David C, Boschi S 1997 Developmental pattern of fetal growth hormone, insulin-like growth factor I, growth hormone binding protein and insulin-like growth factor binding protein-3. Arch Dis Child Fetal Neonatal Ed 77:F100-104

8. Holmes R, Montemagno R, Jones J, Preece M, Rodeck C, Soothill P 1997 Fetal and maternal plasma insulin-like growth factors and binding proteins in pregnancies with appropriate or retarded fetal growth. Early Hum Dev 49:7-17

9. Langford K, Nicolaides K, Miell JP 1998 Maternal and fetal insulin-like growth factors and their binding proteins in the second and third trimesters of human pregnancy. Hum Reprod 13:1389-1393

10. Bocconi L, Mauro F, Maddalena SE, De Iulio C, Tirelli AS, Pace E, Nicolini U 1998 Insulinlike growth factor 1 in controls and growth-retarded fetuses. Fetal Diagn Ther 13:192-196

11. D'Ercole AJ, Willson DF, Underwood LE 1980 Changes in the circulating form of serum somatomedin-C during fetal life. J Clin Endocrinol Metab 51:674-676

12. Bang P, Westgren M, Schwander J, Blum WF, Rosenfeld RG, Stangenberg M 1994 Ontogeny of insulin-like growth factor-binding protein-1, -2, and -3: quantitative measurements by radioimmunoassay in human fetal serum. Pediatr Res 36:528-536

13. Bennett A, Wilson DM, Liu F, Nagashima R, Rosenfeld RG, Hintz RL 1983 Levels of insulin-like growth factors I and II in human cord blood. J Clin Endocrinol Metab 57:609-612

14. Lo HC, Tsao LY, Hsu WY, Chen HN, Yu WK, Chi CY 2002 Relation of cord serum levels of growth hormone, insulin-like growth factors, insulin-like growth factor binding proteins, leptin, and interleukin- 6 with birth weight, birth length, and head circumference in term and preterm neonates. Nutrition 18:604-608

15. Gluckman PD, Johnson-Barrett JJ, Butler JH, Edgar BW, Gunn TR 1983 Studies of insulin-like growth factor -I and -II by specific radioligand assays in umbilical cord blood. Clin Endocrinol (Oxf) 19:405-413

16. Ogilvy-Stuart AL, Hands SJ, Adcock CJ, Holly JM, Matthews DR, Mohamed-Ali V, Yudkin JS, Wilkinson AR, Dunger DB 1998 Insulin, insulin-like growth factor (IGF-I), IGF-binding protein-1, growth hormone, and feeding in the newborn. J Clin Endocrinol Metab 83:3550-3557

17. Christou H, Connors JM, Ziotopoulou M, Hatzidakis V, Papathanassoglou E, Ringer SA, Mantzoros CS 2001 Cord blood leptin and insulin-like growth factor levels are independent predictors of fetal growth. J Clin Endocrinol Metab 86:935-938

18. Isley WL, Underwood LE, Clemmons DR 1984 Changes in plasma somatomedin-C in response to ingestion of diets with variable protein and energy content. JPEN J Parenter Enteral Nutr 8:407-411

19. Clemmons DR, Underwood LE, Dickerson RN, Brown RO, Hak LJ, MacPhee RD, Heizer WD 1985 Use of plasma somatomedin-C/insulin-like growth factor I measurements to monitor the response to nutritional repletion in malnourished patients. Am J Clin Nutr 41:191-198

20. Clemmons DR, Underwood LE 1991 Nutritional regulation of IGF-I and IGF binding proteins. Annu Rev Nutr 11:393-412

21. Donovan SM, Atilano LC, Hintz RL, Wilson DM, Rosenfeld RG 1991 Differential regulation of the insulin-like growth factors (IGF-I and -II) and IGF binding proteins during malnutrition in the neonatal rat. Endocrinology 129:149-157

22. Smith WJ, Underwood LE, Clemmons DR 1995 Effects of caloric or protein restriction on insulin-like growth factor-I (IGF-I) and IGF-binding proteins in children and adults. J Clin Endocrinol Metab 80:443-449

23. Smith LE, Shen W, Perruzzi C, Soker S, Kinose F, Xu X, Robinson G, Driver S, Bischoff J, Zhang B, Schaeffer JM, Senger DR 1999 Regulation of vascular endothelial growth factor-dependent retinal neovascularization by insulin-like growth factor-1 receptor. Nat Med 5:1390-1395

24. Hellstrom A, Perruzzi C, Ju M, Engstrom E, Hard AL, Liu JL, Albertsson-Wiklan K, Carlsson B, Niklasson A, Sjodell L, LeRoith D, Senger DR, Smith LE 2001 Low IGF-I suppresses VEGF-survival signaling in retinal endothelial cells: direct correlation with clinical retinopathy of prematurity. Proc Natl Acad Sci U S A 98:58045808

25. Hellstrom A, Engstrom E, Hard AL, Albertsson-Wikland K, Carlsson B, Niklasson A Lofquist C, Svensson E, Holm S, Ewald U, Holmstrom G, Smith LE 2003 Postnatal serum insulin-like growth factor I deficiency is associated with retinopathy of prematurity and other complications of premature birth. Pediatrics 112:1016-1020
26. Michaelsen KF, Pedersen SB, Skafte L, Jaeger P, Peitersen B 1988 Infrared analysis for determining macronutrients in human milk. J Pediatr Gastroenterol Nutr 7:229235

27. Polberger S, Lonnerdal B 1993 Simple and rapid macronutrient analysis of human milk for individualized fortification: basis for improved nutritional management of very-low-birth-weight infants? J Pediatr Gastroenterol Nutr 17:283-290

28. 1985 American Academy of Pediatrics Committee on Nutrition: Nutritional needs of low-birth-weight infants. Pediatrics 75:976-986

29. 1987 Nutrition and feeding of preterm infants. Committee on Nutrition of the Preterm Infant, European Society of Paediatric Gastroenterology and Nutrition. Acta Paediatr Scand Suppl 336:1-14

30. Shennan AT, Dunn MS, Ohlsson A, Lennox K, Hoskins EM 1988 Abnormal pulmonary outcomes in premature infants: prediction from oxygen requirement in the neonatal period. Pediatrics 82:527-532

31. 1984 An international classification of retinopathy of prematurity. Prepared by an international committee. Br J Ophthalmol 68:690-697

32. Blum WF, Breier BH 1994 Radioimmunoassays for IGFs and IGFBPs. Growth Regul 4(suppl 1):11-19

33. Marsal K, Persson PH, Larsen T, Lilja H, Selbing A, Sultan B 1996 Intrauterine growth curves based on ultrasonically estimated foetal weights. Acta Paediatr $85: 843-848$

34. Lucas A, Hudson GJ 1984 Preterm milk as a source of protein for low birthweight infants. Arch Dis Child 59:831-836

35. Smith WJ, Underwood LE, Keyes L, Clemmons DR 1997 Use of insulin-like growth factor I (IGF-I) and IGF-binding protein measurements to monitor feeding of premature infants. J Clin Endocrinol Metab 82:3982-3988

36. Oliver MH, Harding JE, Breier BH, Evans PC, Gluckman PD 1993 Glucose but not a mixed amino acid infusion regulates plasma insulin-like growth factor-I concentrations in fetal sheep. Pediatr Res 34:62-65

37. Price WA, Lee E, Maynor A, Stiles AD, Clemmons DR 2001 Relation between serum insulinlike growth factor-1, insulinlike growth factor binding protein-2, and insulinlike growth factor binding protein-3 and nutritional intake in premature infants with bronchopulmonary dysplasia. J Pediatr Gastroenterol Nutr 32:542-549

38. Rajaram S, Carlson SE, Koo WW, Rangachari A, Kelly DP 1995 Insulin-like growth factor (IGF)-I and IGF-binding protein 3 during the first year in term and preterm infants. Pediatr Res 37:581-585

39. Lofqvist C, Andersson E, Gelander L, Rosberg S, Blum WF, Albertsson Wikland K 2001 Reference values for IGF-I throughout childhood and adolescence: a model that accounts simultaneously for the effect of gender, age, and puberty. J Clin Endocrinol Metab 86:5870-5876

40. Juul A 2001 Determination of insulin-like growth factor I in children: normal values and clinical use. Horm Res 55(suppl 2):94-99

41. Kajantie E, Dunkel L, Rutanen EM, Seppala M, Koistinen R, Sarnesto A, Andersson S 2002 IGF-I, IGF binding protein (IGFBP)-3, phosphoisoforms of IGFBP-1, and postnatal growth in very low birth weight infants. J Clin Endocrinol Metab 87:21712179

42. Bloomfield FH, Knight DB, Breier BH, Harding JE 2001 Growth restriction in dexamethasone-treated preterm infants may be mediated by reduced IGF-I and IGFBP-3 plasma concentrations. Clin Endocrinol (Oxf) 54:235-242

43. Barrios V, Argente J, Pozo J, Hervas F, Munoz MT, Sanchez JI, Hernandez M 1996 Insulin-like growth factor I, insulin-like growth factor binding proteins, and growth hormone binding protein in Spanish premature and full-term newborns. Horm Res 46:130-137

44. Bankowski E, Palka J, Jaworski S 2000 Preeclampsia is associated with alterations in insulin-like growth factor (IGF)-1 and IGF-binding proteins in Wharton's jelly of the umbilical cord. Clin Chem Lab Med 38:603-608

45. Jacobsson B, Mattsby-Baltzer I, Andersch B, Bokstrom H, Holst RM, Nikolaitchouk N, Wennerholm UB, Hagberg H 2003 Microbial invasion and cytokine response in amniotic fluid in a Swedish population of women with preterm prelabor rupture of membranes. Acta Obstet Gynecol Scand 82:423-431

46. Gronbek H, Thogersen T, Frystyk J, Vilstrup H, Flyvbjerg A, Dahlerup JF 2002 Low free and total insulinlike growth factor I (IGF-I) and IGF binding protein-3 levels in chronic inflammatory bowel disease: partial normalization during prednisolone treatment. Am J Gastroenterol 97:673-678

47. Ogueh O, Miell JP, Jones JC, Jones JS, Alaghband-Zadeh J, Johnson MR 2000 Antenatal dexamethasone and the growth hormone-insulin-like growth factor axis. Hum Reprod 15:1403-1406 